\title{
OJE 法による実践型教育と教育効果
}

On a Practical Exercise with OJE (On the Job Education) and Educational Effects

倉 敷 哲 生※1

Tetsusei KURASHIKI

松 村 暢 彦※1

Nobuhiko MATSUMURA

\author{
上西啓介※1 \\ Keisuke UENISHI \\ 村 田 雅 人*1 \\ Masato MURATA
座 古 勝 ${ }^{* 1}$
Masaru ZAKO

\author{
清 野 智 史※1 \\ Satoshi SEINO \\ 山 本 孝 夫※ 1 \\ Takao YAMAMOTO
}
加 賀 有津子 ${ }^{* 1}$
Atsuko KAGA

佐 藤 武 彦*1

Takehiko SATO

In this paper, an educational program for practical exercise based on OJE (On the Job Education) method has been described. The program consists of two parts; one is a long-term group seminar for a year to educate the planning and problem solving through aggressive selfdevelopments, another is a short-term program for 2 days to educate leadership. In the group seminar, graduate students of engineering and economics have discussed. The procedure and the educational effect are described. OJE is an educational method which has been made a plan to generate the motivation. As the participants have given a good score in the evaluation to our educational method, it is recognized that OJE is an effective method.

Keywords : On the Job Education, Practical Exercise, Leadership Program, Group Seminar キーワード：OJE，実践型演習，リーダー育成，グループ演習

\section{1.はじめに}

人間生活に関わる物財・情報から都市・地域環境ま でも含めた「モノ造り」に関して，技術者・利用者の 知である「技術知」をデザインし，それを用いて社会 や経済の活性化に貢献できる人材を育成することを目 的として, 大阪大学大学院工学研究科と経済学研究科 が連携し, 工学研究科内にビジネスエンジニアリング 専攻（以下BE専攻と略す）が平成16年 4 月に設置さ れた. 本専攻では, 新たな工学教育方法としてOJE $(\mathrm{On}$ the Job Education）法を提案し実施している ${ }^{1)}$.

企業では，米国で考案され社員教育に秀れたOJT (On the Job Training) により, 上司がスタッフを 1 対 1 で教育している. 最近では年代間のコミュニケー ションの困難さから, より効果的な教育手法が望まれ ている. 特に, 即戦力人材や人員不足を理由に, 本来 の目的である自己啓発にまで至っていないのが現状で ある. 一方, 大学でもこのような社会の要求に対応し た人材教育法が必要となっているが, OJTのような 1 対 1 の教育は非効率であり実施も困難である. そこで, トレーニングではなく教育に主眼をおき，大学での工

平成 20 年 2 月 28 日受付

$\approx 1$ 大阪大学大学院工学研究科
学教育に相応しい方法として開発したのがOJE法であ る.

前報 ${ }^{1)}$ では，本専攻の設立趣旨抢よびカリキュラ ムの特徵を中心に記載した. 平成16年 4 月の設立以降, 本専攻では教育効果や効率の観点から複数の科目を OJE法により実施している，そこで，本専攻の実践型 教育の取り組みとして, 少人数グループで実施してい る長期型OJE演習および短期集中型OJE演習の内容と 教育効果について記述する. さらに, 平成19年 3 月に は経営学修士 (MBA) と工学修士 (ME) のダブルディ グリー第一期生を輩出している。 そこで行った教育や 経済学研究科学生を交えたOJEについて記述する。

\section{OJE法について}

OJTおよびOJEの相違として, 眓 1 に各々のプロセ スを示す. OJTでは, 図 1 (a) に示す育成必要点の把 握, 育成目標の設定, 目標達成への取り組み, 成果の 確認の各段階が実施される. しかし, 常に外的動機付 けを与え続ける必要があり, 本来の目的である自己啓 発にまで至っていないのが現状である。

OJE法では, 図 1 (b) に示すように, 外的動機付け から始め, 学習過程で内的動機付けに変わっていく知 識修得に重点を置いた教育プログラムとしている. 少 


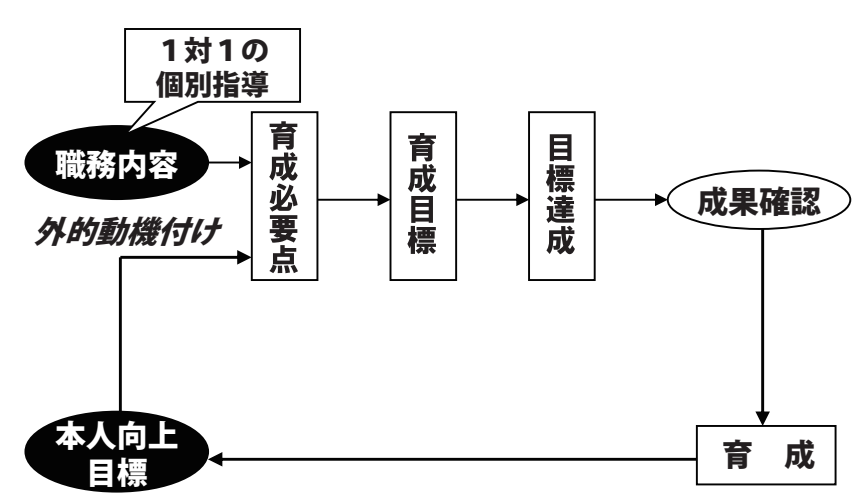

図 1 (a) OJTの流れ

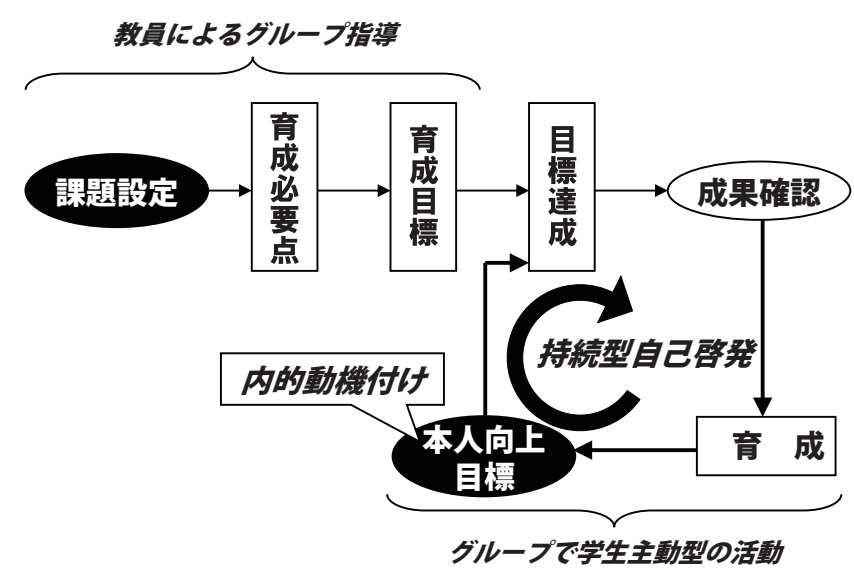

図 1 (b) OJEの流れ

図 1 OJT と OJE

人数グループで問題点を把握し, 解決手法を提案させ それを実行させることで，単なる訓練では無く，目的 意識や技術融合やそのマネジメントを教育し，持続的 な自己啓発を目指すものである．特に，ものづくりに は高度な専門知識に加えてその周辺領域を含む広範 囲にわたる知見が必要である。そのため，自らが目標 を生み出して実行し, 学んだ内容を他人に伝え議論す る能力を効果的に伸ばすことを特徵としている.

\section{3. 通年型演習科目「BE研究」}

\section{1 演習の理念}

大学の工学教育における産業界の要望として,「問 題提起 - 解決能力 」, 「論理的思考能力」, 「行動力 - 実 行力」は常に上位にあり, 企業でも重要な能力・素質 として挙げている．OJE法はこうした時代のニーズを 十分に汲み取り，演習の中に下記の項目を掲げ，教育 を実施している。

（1）徹底したグループ討論

(2) 研究成果に辿り着くプロセス（戦略）の重視

（3）既存の提案事項の問題点を分析し代替案を提示

（4）試作品開発や提案事業試行など主体的に行動

1,2 週間程度の短期間型や通年に及ぶ長期間型科 目を組み合わせ，これらを科目群としている点にも本
表 1 研究テーマー覧

(a) 平成 16 年度

\begin{tabular}{|l|l|}
\hline 商品企画・コスト & $\begin{array}{l}\text { ・高齢者補助器具の商品企画開発 } \\
\text { ・エニットバスの低価格化 }\end{array}$ \\
\hline 環境配慮 & $\begin{array}{l}\text { ・伝統技術を現代のテクノロジーヘ } \\
\text { ・テーマパークの省エネルギー }\end{array}$ \\
\hline マネジメント & $\begin{array}{l}\text { ・大学内自転車交通マネジメント } \\
\text { ・事業統合に伴うオフィス空間の検討 }\end{array}$ \\
\hline 都市・地域再生 & $\begin{array}{l}\text { ・ 中山間地域の活性化 } \\
\text { ・老朽化した郊外団地の再生 } \\
\text { ·大阪市○○地区の再開発 }\end{array}$ \\
\hline
\end{tabular}

(b) 平成 17 年度

\begin{tabular}{|l|l|}
\hline 商品企画・コスト & $\begin{array}{l}\text { ・太陽電池をどこに使うか? } \\
\text { ・イフラ構造物の高機能化とライ } \\
\text { フサクルコスト }\end{array}$ \\
\hline 環境配慮 & $\begin{array}{l}\text { ・和紙を活用したビジネス提案 } \\
\text { ·省エネルギーをビジネスへ }\end{array}$ \\
\hline $\begin{array}{l}\text { 住宅・オフィス } \\
\text { 効率化 }\end{array}$ & $\begin{array}{l}\text { ・他のビルヘのオフィス移転コンサ } \\
\text { ルティング } \\
\text { ・エネルギー負荷を } 1 / 4 \text { にする住宅 }\end{array}$ \\
\hline $\begin{array}{l}\text { 都市・ } \\
\text { 地域活性 }\end{array}$ & $\begin{array}{l}\text { ・持続可能な次世代のまちづくり } \\
\text { ・御堂筋再生方策の提案 }\end{array}$ \\
\hline
\end{tabular}

(c) 平成 18 年度

\begin{tabular}{|l|l|}
\hline 商品企画・コスト & $\begin{array}{l}\text { ・携帯用機器を考える } \\
\text { ・構造物省エネのための緑化材 }\end{array}$ \\
\hline 資源管理, \\
マネジメント & $\begin{array}{l}\text { ・大阪大学の環境教育 } \\
\text { ·阪大工学部のスペース利用効率向上 }\end{array}$ \\
\hline 住宅・都市再生 & $\begin{array}{l}\text { ・地域資源を活かした地域づくり } \\
\text { ・人口減少時代での郊外住宅団地の } \\
\text { 再生 }\end{array}$ \\
\hline 都市・地域活性 & $\begin{array}{l}\text { ・生き生きとした商店街の戦略と実践 } \\
\text { ・情報発信による御堂筋活性化研究 }\end{array}$ \\
\hline
\end{tabular}

専攻の教育の特徵がある。このうち, 当専攻全教員が 担当し, 博士前期課程 1 年生を対象としたOJE科目「ビ ジネスエンジニアリング (BE) 研究」(通年, 週 3 時 間）について以下に説明する。

\section{2 実施内容}

本演習では, 商品企画やコスト, 人・情報・モノの 流れのマネジメント, 環境配慮や都市・地域再生活性 化など多岐に亘るテーマを設定している. 表 1 に過去 3 年間のテーマ一覧を示す。毎年テーマは変更し, 1 テーマ 4〜 5 名のグループで実施している. 各グルー プには教員 1 名を配置し, 3 つのテーマは連携教員 (企 業), 残りのテーマは本専攻の専任准教授・講師が指 導している. 1 企業当たり教授 2 名, 准教授 1 名が連 携教員に就任しており, 企業のインターンシップ効果 を学内で実施するのに大きな成果をもたらしている。

実施は 1 年間で, 図 2 に示す第 1,2 学期に分けて 実施している。第 1 学期では, 各テーマの調查, 問題 点分析, 検討・提案の流れで実施する. 明確な解の無 
い課題に対して, 学生自身の主体性を基に演習に取り 組み，積極的に現場調査や企業訪問，ヒアリング等を 実施させる。グループで調査項目の整理やレポート作 成などの時間管理，ワークシェアを通じて，横断的思 考・企画能力・コミュニケーション力の向上を図り, 実践的な研究展開能力の素地を養っている。学期末に は, 学生, 学内教員, 企業からの連携教員の参加の下 で，公開の成果発表会を行い，成果を問う形式として いる. また，その成果を第 1 学期成果報告書として作 成している.

第 2 学期では, 2 つコースを設定している. 第 1 学期に実施した班の提案事項について，メンバーを入 れ替えた班が同じテーマについて異なった角度からの 分析・評価を実施し, 代替案を提示させる「エクスチェ ンジ」コース, また, 第 1 学期の提案を具現化するた め, 実際に試作品開発や提案事業の試行を行い, 問題 点を洗い出し提案を改善する「トライアル」コースで ある。指摘された点等を反映して，第 1 学期成果報告 書を加筆・修正し，最終報告書を作成している。

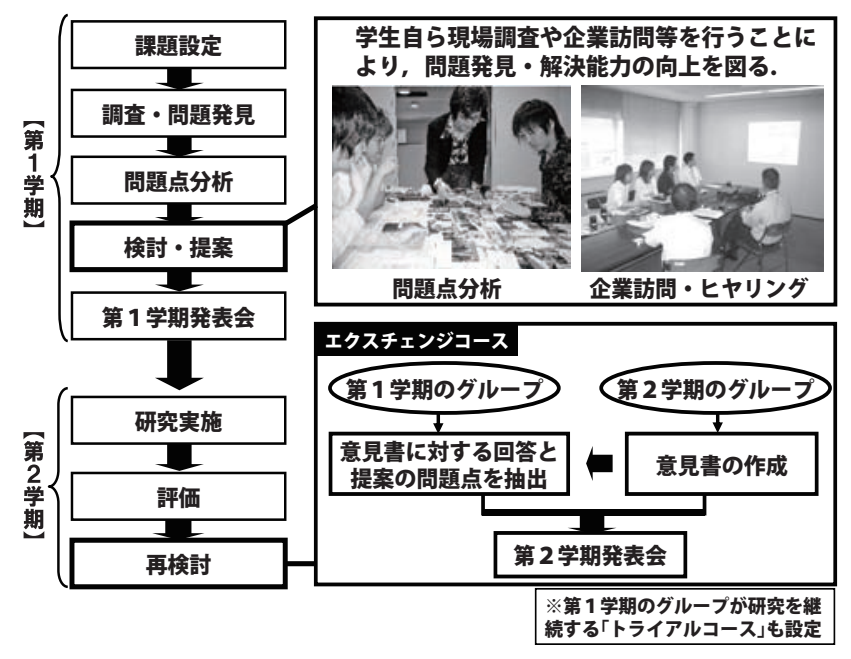

図 $2 \mathrm{BE}$ 研究実施の流れ

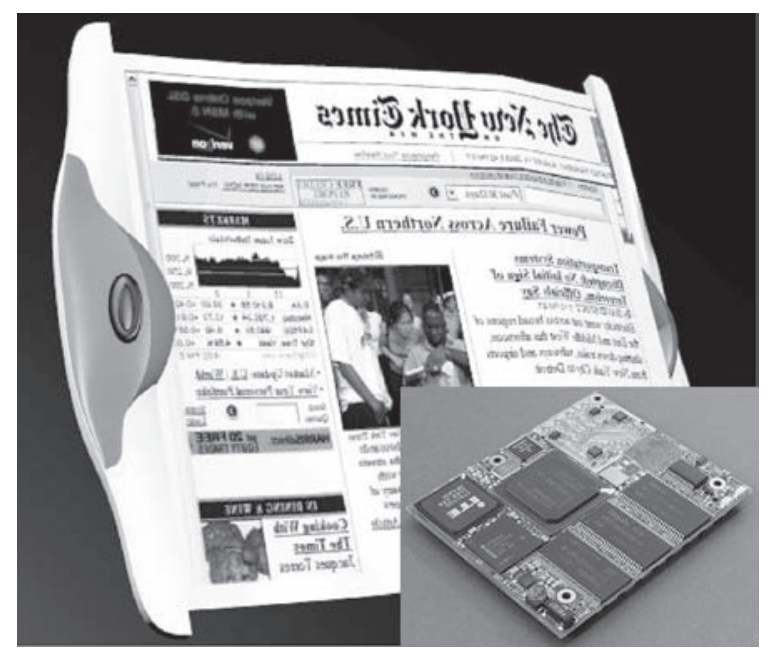

図 3 テーマ「携帯機器を考える」の成果の一例
図 3,4 に成果の一例を示す。図 3 はテーマ「携帯 機器を考える」の成果の一例である. 本棚を持ち運び たいというユーザのニーズを汲み取り，携帯性や見や すさを追求した携帯機器の技術的検証を行い, 学生自 身が電子部品を組み上げプロトタイプを提案している.

また，図 4 はテーマ「商店街の活性化」の成果の一 例である. 活性化の定義や事例調査, アンケート分析 を実施し, 学生自らイベントを提案・企画し, 行政・ 市民とともに連携し運営した。 イベントの模様は広報 誌でも報道されている2).

\section{3 教育効果}

図 5 に座学主体の科目と, 平成 17,18 年度実施の OJE科目の評価結果を示す. 各項目を $0 \sim 5$ 点で評価 されたものである。評価機関からは，一般に平均点が 3 であるのに対し, OJE科目群は問題発見・解決力, プレゼンテーション等のいずれの項目も 4 以上であ り, 図 5 の座学主体科目に比べればOJE法は高い評価 であるとの評を得ている. 特に, 履修価值の項目で 4.56 の評点を得ている点については, 学生がOJEに関して

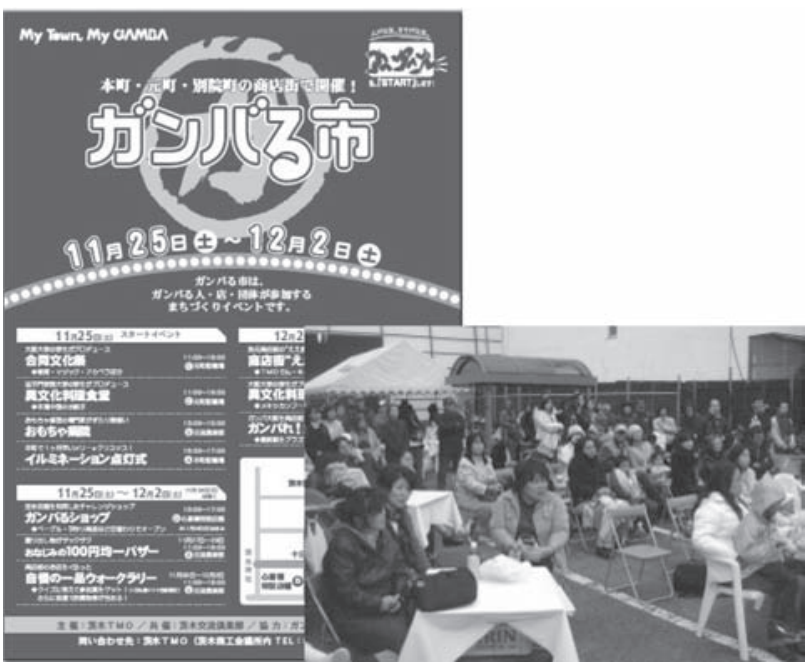

図 4 テーマ「商店街の活性化」の成果の一例

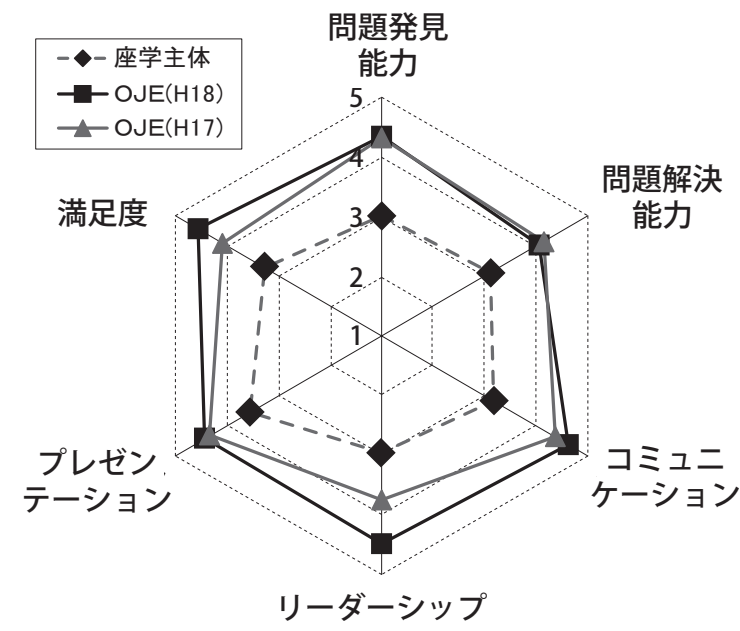

図 5 評価結果 
非常に高く評価している. OJE法を経験したい理由で, 専攻への進学希望者も増えている.

さらに, BE研究の第 1,2 学期発表会終了時の 2 回 に分けて受講生にアンケートを実施した．別の第三者 教育評価機関に委託LOJE教育の効果を分析した。平 成18年度受講生について, 結果の一部を以下に示す.

【現場調查, ヒアリングについて】

関係各位・ステークホルダーを認識した上での実行 が十分なされており，多面的観点からの情報収集に努 めたことも伺える. 第 1 回目と比べ, 第 2 回目の調査 において受講生の成長が見受けられ，改善したものと 考察できる.

【問題発見プロセスについて】

問題をイメージではなく事実に基づいて捉えようと したか，本当の問題に行き着くまで事実を探し続けた かといった項目について，全体的に評価は高く問題発 見に必要な事実の探求が概ね出来ている.

【関係者の立場を踏まえた提案について】

情報収集に対する評価と同様，十分な配慮が見受け られている．また，専門分野以外も分け隔てなく意見 したかについて, 比較的高い評価回答を得ている.

【他のメンバーの考え方や人柄について】

他のメンバーの意見を傾聴したかという質問につい ては評価が高く, 相互認識をしっかり行えている.

【他グループの発表・指摘について】

傾聴は注意深く行い，自己の意見を持つように心が けたという回答が多い。また, 他グループからの指摘・ 質問から得た教訓を元に次のステップを構築している 点は評価できる。

以上より,「問題への深い探求」や「現場調査・企 業訪問への行動力」,「傾聴力」,「外部からの指摘を参 照し自己向上」等の項目に高い評価を得ている. 図 5 にある「問題解決能力」も含めて,これらの評価から, 学生自らが目標を生み出して実行し，学んだ内容を他 人に伝え積極的に議論し自己研鑚に努めたことが示唆 され，自己啓発を目指すOJEの効果が確認できる.

\section{4. リーダー養成を目指した選抜セミナー}

\section{1 セミナーの目的}

本専攻では, リーダーとしての素質をさらに磨く事 を目的として，「リーダー育成セミナー」と名づけた 選抜セミナーを実施している。各界の著名人(経営者, 経営指導者, 企画部, 研究所所長など）を講師として 招き, 数日間の合宿形式での演習を行う点が特徵であ る. 合宿形式として講師と学生の間の接触と討論を長 時間集中して行い, 密度の高い学習と討論を行うこと でリーダーに必要な素養を育成することが狙いであ る。リーダー育成セミナーの概要と, その成果につい て以下に説明する。

\section{2 実施方法}

リーダー育成セミナーの履修に際しては，受講者の 選抜を行っている。履修の前提として, 経済学研究科 経営学専攻との互換科目 7 科目から 2 科目 4 単位以上 履修していること，もしくは，リーダーとしての資質 の要求が高いと主査・副査が認める種々のプロジェク ト・共同研究・アントレプレナーなどの活動（ロボカッ プ, 産官学連携プロジェクト, ベンチャー企業等の起 業, 研究フォーラムの企画・運営など) において, リー ダー的役割をもって参加すること，のどちらかの要件 を満たしており，さらに面接審査に合格することを必 要要件としている.

セミナーは, 各界の著名人による講演と, 少人数で 行うグループワークにより構成されている. 講演では, 講演後の討論に時間を割き, 学生と講師がより密に接 触できるよう配慮している。グループワークはOJE方 式で行ったが, 以下の特徵を有している.

(1) 短期集中形式

短期集中の合宿形式とすることで, 学生と学生, 講 師と学生の間の接触と討論を長時間集中して行ってい る. 表 2 に，プログラムの一例を示す．逃げ場の無い 状況下で, 密度の高い学習と討論を行うことを目的と している.

（2）課題設定と少人数グループワーク

表 2 リーダー育成セミナーのプログラムの一例

\begin{tabular}{|c|c|c|}
\hline \multirow{5}{*}{$\begin{array}{l}\text { 昌 } \\
\text { 严 }\end{array}$} & $13: 00$ & 特別講演 (1) \\
\hline & $15: 00$ & 特別講演(2) \\
\hline & $18: 00$ & 夕食 \\
\hline & $19: 00$ & 課題説明 \\
\hline & $19: 30 \sim$ & グループ分け・グループ討論 \\
\hline \multirow{6}{*}{$\begin{array}{l}2 \\
\text { 目 }\end{array}$} & $8: 30$ & 朝食 \\
\hline & $9: 00$ & 特別講演 (3) \\
\hline & $11: 00$ & 各班の課題発表と評価 \\
\hline & $12: 30$ & 昼食 \\
\hline & $13: 30$ & 各班の課題発表と評価 \\
\hline & $17: 30$ & 講評 \\
\hline
\end{tabular}

表 3 第 1 回リーダー育成セミナー

\begin{tabular}{|l|c|}
\hline 期 日 & 平成 18 年 3 月 $17 \sim 18$ 日 \\
\hline 参加学生 & 30 名 \\
\hline 既 略 & \\
\hline リーダーとして必要な「意思決定とビジネス展開」教育 \\
の一環として, 企業内に拈ける技術開発や製品開発項目 \\
を決定する手順を学ばせた. 具体的には, 企業での研究 \\
企画経験者の講演を聴き, その後少人数でのグループ演 \\
習を行った. 課題として, 企業の財務諸表等の情報から, \\
今後その企業がどのようなプロジェクトを立ち上げるべ \\
きか等の企業方針について提案させた. 対象企業はグ \\
ループ毎に変え, 参加者に出来る限り多くのことが学べ \\
るように配虑した. \\
\hline
\end{tabular}


表 4 第 2 回リーダー育成セミナー

\begin{tabular}{|c|c|}
\hline & 平成 18 年 9 月 $25 \sim 26$ 日 \\
\hline 参加学生 & \\
\hline \\
\hline \multicolumn{2}{|c|}{ 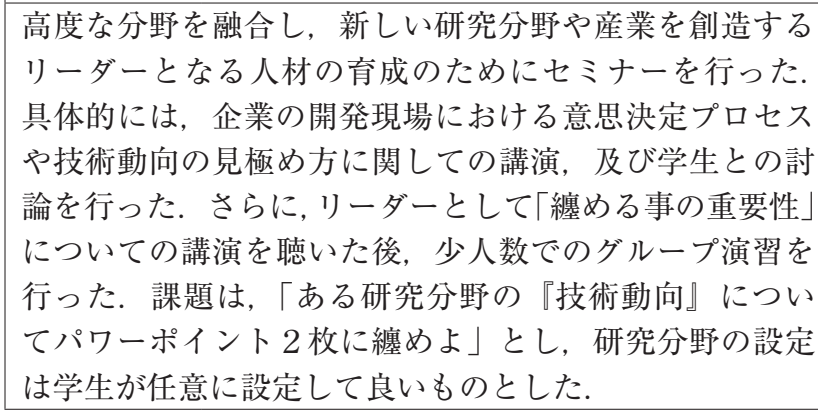 } \\
\hline
\end{tabular}

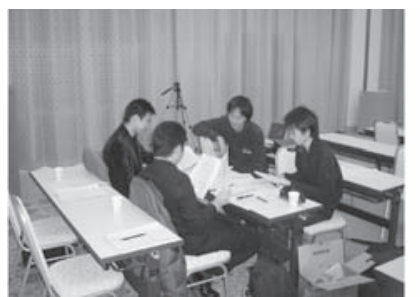

ディスカッションの様子

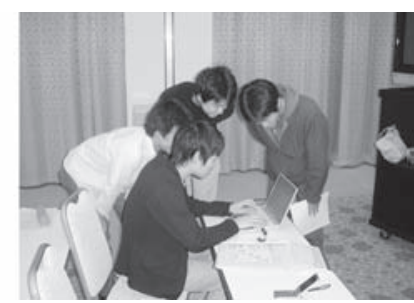

ネットの使用は15分間に限定
演習を通じてリーダーとして必要な考え方を身に付 けるような課題設定を行っている。 一班 $3 \sim 6$ 名で課 題に取り組む事とした。ただし，グループワークの中 でのリーダーシップが評価対象という訳ではない.

（3）ネット使用の制限

あくまで『自分の頭で考える』ことが重要との認識 から，インターネットの使用時間を制限した。一つの 演習課題に対し，接続時間を15分間に限定した。眓 6 にグループワークの模様を示す。

（4）成果の発表

グループワークの成果をプレゼンテーション資料と して纒め, 10分〜 15分程度の発表を行い, 講師の先 生方の講評を頂く.

\section{3 実施内容・効果}

表 3，4にリーダー育成セミナーの内容を示す．実 社会でリーダーとして活躍している講師による講演で は，普段聞くことのできない失敗事例をも含めた話を 聞くことができ，学生にとっても非常に貴重な経験で あった事と思う。討論も積極的に行われ，学生らの強 い熱意を感じる事ができた.

また, グループワークは非常に熱意を持って取り組 んでいた。限られた時間の中で行うという制約の中, 課題の意図を理解しそれを表現するという意味におい て,プレゼンテーションのレベルは高いものであった. セミナー終了後, 企業からの講師の評価として,「第 1 回より第 2 回の方が良かった」,「学生が大変意欲的 であそこまで出来るとは思わなかった」等の講評を頂 いており，学生が成長していることが伺われた，第 2

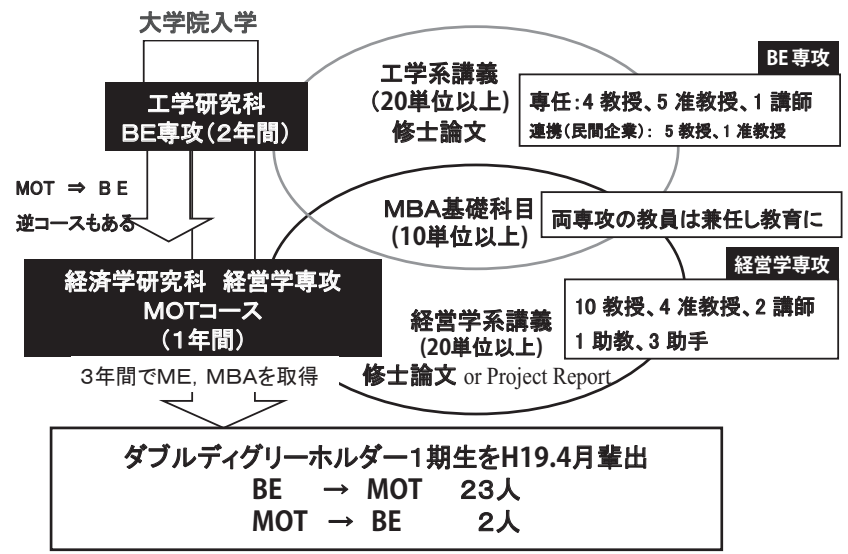

図 $7 \mathrm{ME} / \mathrm{MBA}$ 両修士号を修得するプロセス

回目以降, 学生自身の参加意欲も増しており, こうし たセミナーが学生の自己研鑚に繋がっている.

なお，リーダー育成セミナーでの活動およびレポー トが優秀であると認められれば,リーダー認定証を交 付している.

\section{5. 工学・経営学両修士号取得学生の輩出}

\section{1 相互互換プログラムの概要}

工学研究科BE専攻は, 本学大学院経済学研究科経 営学系専攻MOTコースと連携し, 工学・経済学研究 科に扔ける幅広い専門分野を背景にして, 平成16年 度より 3 年間で経営学修士（MBA）および工学修士 (ME) のダブルディグリーを取得できる相互互換プ ログラムを実施している.

図 7 に大学院工学研究科入学から 3 年間で両修士 号を修得するプロセスの概要を示す. BE専攻の博士 前期課程では, 工学研究科で開講する専門科目群, OJE演習科目群に加えて, 経済学研究科で開講される MBA基礎科目群が用意されている. 工学修士を取得 するためには，前述したビジネスエンジニアリング研 究 (必修科目) を含めた 30 単位取得と修士論文を修了 要件としている. MBA基礎科目群としては 7 科目 14 単位を開講し, 全て工学修士の履修要件としてカウ ントできる. 3 年間でダブルデイグリーを取得する ためには, 工学研究科在籍中にMBA基礎科目群から 10 単位以上の取得を義務付けている。.以上とは逆に, MBAを取得した経営学系専攻の学生がBE専攻へ進学 する場合も同様な要件となっている.

\section{2 各学年における教育・研究活動}

(1) 博士前期課程 1 年生

技術及び経営の両分野に拧ける基礎知識の習得を目 的として, 両専攻で提供される基礎科目を履修する. また, BE研究や知的財産権などのOJE演習科目履修 を通じて, 研究・プロジェクトに関わる企画・立案か ら問題解決までの一連の作業を経験する。これにより， 企画力・問題分析能力やチームネットワーク構成力・ コミュニケーション能力に加えて, プロジェクト遂行 
に必要な技術・経営・ニーズあるいは顧客・自分・競 合といった幅広い視点を涵養する。

MBA基礎科目は工学研究科とは異なる豊中キャン パスにて開講されているが, カリキュラムの都合によ り豊中キャンパスへ移動することが出来ない学生に対 しても，ネットワークを利用した遠隔授業システムを 導入することにより, 吹田キャンパスでの聴講を可能 にし，両専攻の教員・学生間の交流を深める努力をし ている.

以上の工学修士取得のためのカリキュラムとは別 に，前述のリーダー育成セミナーや， $\mathrm{BE}$ 研究成果を 広く社会に向けて発表するビジネスエンジニアリング シンポジウムを毎年開催し, プレゼン能力, 討論力を 涵養すると同時に，自分が社会に出た際に果たすべき 役割を知り, 個人のマインドアップの機会を与えてい る. 以上のように, 1 年目はカリキュラム・イベント が盛り沢山で大変忙しい毎日を過ごすが, その過程は 貴重で充実したものであったと振り返る学生が多い.

(2) 博士前期課程 2 年生

1 年生の間に単位取得に奔走し，修了要件を満たす 学生が大半であるので, 2 年生は他の専攻と同様に, 自分の専門分野を深める修士論文研究にほとんどの 時間を費やすことになる。ただし，特許調査などによ り自分の研究の社会的ポジション分析をするなど, 専 門知識・スキルを深めるだけでなく，学生が幅広い応 用力をも兼ね備え, 社会ニーズを理解して一歩踏み出 て提案をすることができるよう研究指導に留意してい る.

またリーダー育成セミナーなどには引き続き参加 し，自身のマインドアップをすると同時に，修士 1 年 生に積極的に指導を行い，新しい発見と既習事項で あってもその理解を深める良い機会となっている.

MOTコースへ進学するためには，8月および12月に 実施される大学院入試を受験・合格する必要があり, $\mathrm{BE}$ 専攻の第一期生は20名を越える学生が合格した. また, MOTコース一期生も 2 名が工学研究科へ進学 した。

(3) 博士前期課程 3 年生

3 年目は新しい研究科での生活となる. 図 8 にBE 専攻からMOTコースへ，およびMOTコースからBE 専攻へ進学したそれぞれの学生の各々の $2 \cdot 3$ 年次に おける主な研究の概略を示す。両専攻の学生ともに, 修士の修了要件を満たすために 1 年間で20単位もの講 義・演習を受講する必要がある。また，修士研究およ び就職活動も併行して行う必要があるため, 引き続き 多忙な毎日を過ごすことになる。

MOTコースでの修士研究のテーマの選択は大きく 二つのパターンに大別される。一つは, 例えば新産業 振興のための特許政策のあり方など, 工学研究科で 行った研究内容とはあまり関連性のない, 全く新しい

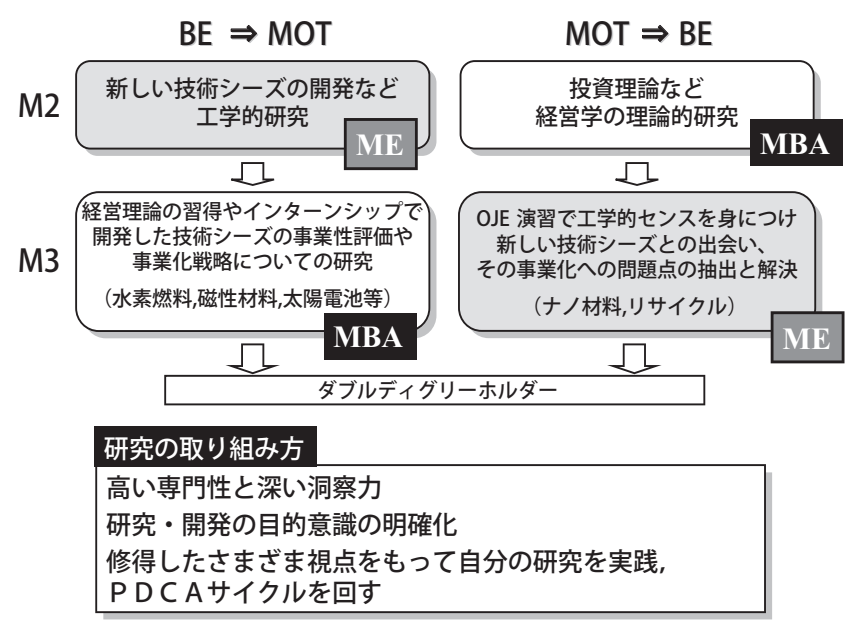

図 8 博士前期課程 $2 \cdot 3$ 年目の活動

テーマの選択である. 当然のことながら, その分析方 法はMOTコースの指導教員からの助言を反映したも のになるが, それでも工学研究科で培ったスキル・価 值観をもって独自の分析を試み, 高い評価を得た取り 組みも数多く見られた。もう一つのパターンは, 工学 研究科時代に取り組んだ技術シーズを題材に, その事 業性評価や事業化戦略についての研究を行なうことで ある. 水素燃料, 磁性材料, 太陽電池, 環境材料など様々 な技術シーズについて, 経営の観点から再度見つめ直 すことにより，新たな方向からの技術開発戦略を立て る必要性を体感した学生も少なくなかった。また，立 案した事業化プランの具現性をチェックするために, インターンシップなどを活用した学生も多数いた.

\section{3 MOTコース学生を交えたOJE}

博士前期課程 1 年次におけるMBA基礎科目および OJE演習科目では, BE専攻の学生とMOTコースの学 生が一緒に受講し, 共同で課題に取り組み, その成果 を発表する機会も多い. 互いの分野の学生の考え方を 知り, そこから新しい提案・考察を導き出す良い教育 の場となっている.

また, MOTコースからBE専攻に進学した学生は, OJE演習で工学的センスを身につけ, 更にはナノ材料, リサイクル技術などの新しい技術シーズと出会い, そ の事業化への問題点の抽出と解決を修士研究にて行っ ている. 工学研究科 2 年生と遜色ない完成度の高い修 士論文を完成している

\section{6. おわりに}

大阪大学大学院工学研究科ビジネスエンジニアリン グ専攻における実践型演習の取り組みとして, OJE法 に基づき, 博士前期課程 1 年生を対象とした長期型 OJE演習の内容と教育効果について述べた。 これらの 教育成果に基づき, 教育スキルに関する自己点検の促 進を図り, 次の教育へのフィードバックを実施し, 人 材育成の効果的手法に発展させたいと考える.

また、リーダー育成を目的とした短期集中OJE演習 
の内容と効果について述べた. 本専攻の理念の一つで ある「産業界で活躍するリーダー育成」を目指し，今 後も継続して行っていく予定である.

さらに, 工学・経営学両修士号取得学生の輩出のた めの相互互換プログラムを示し, 各学年における教育・ 研究活動を記した．MOTコースとBE専攻との協働に より教育プログラムを更に活性化し, 社会のイノベー ションリーダーとしての責務を遂行できる人材などを 育成していきたいと考える。

\section{謝 辞}

本専攻のOJE演習実施にあたり，連携教員としてご 尽力頂いた濱 惠介氏, 柳父行二氏, 篠原 祥氏（大阪 ガス(株)，また，リーダー育成セミナーに関し尽力頂 いた篭橋雄二氏（鳥居薬品株）に謝意申し上げる.工 学・経営学相互互換プログラムに際し, 大阪大学大学 院工学研究科経済学専攻の先生方に深謝申し上げる.

なお，本専攻の取り組みは，文部科学省 魅力ある 大学院教育イニシアティブ「先導的教育研究融合プロ グラム」(平成17，18年度）および経済産業省 産学連
携製造中核人材育成事業「OJEによるものづくり高度 人材育成」(平成 17,18 年度) として採択されたもの である。関係各位に深謝申し上げる。

\section{参 考 文 献}

1 ) 座古 勝, 他：OJE方式による実践型演習, 工学教 育, $54-2$, pp. $69-75,2006$

2 ) 産経新聞：2006年12月 3 日号, 朝刊

\section{著 者 紹 介}

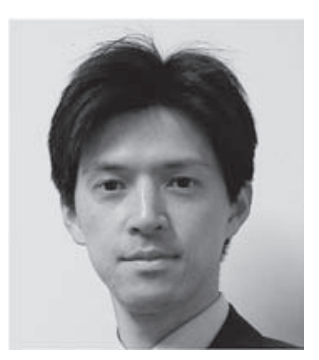

\section{倉敷 哲生}

1997年 大阪大学大学院工学研究科博士後 期課程修了, 博士 (工学)

大阪大学工学部助手を経て, 現在, 大阪 大学大学院工学研究科ビジネスエンジニ アリング専攻 准教授

専門分野: 信頼性工学, 複合材料工学

e-mail : kurasiki@mit.eng.osaka-u.ac.jp

http : //www.mit.eng.osaka-u.ac.jp 